\title{
PENGARUH LEVEL ONGGOK SEBAGAI ADITIF TERHADAP KUALITAS SILASE ISI RUMEN SAPI
}

\section{THE EFFECT OF CASSAVA POMACE LEVEL AS ADDITIVE ON QUALITY OF RUMEN CONTENT SILAGE}

\author{
Ristianto Utomo*, Subur Priyono Sasmito Budhi, dan Irma Fitri Astuti \\ Fakultas Peternakan, Universitas Gadjah Mada, Jl. Fauna No. 3, Bulaksumur, Yogyakarta, 55281
}

\section{INTISARI}

Penelitian ini bertujuan untuk mengetahui pengaruh level pemberian onggok sebagai aditif terhadap kualitas silase yang dibuat dari isi rumen sapi. Terdapat tiga level perlakuan penambahan onggok, yaitu 0 (kontrol), 15, dan $30 \%$ dari berat bahan kering isi rumen sapi, dan tiga lama peram yaitu 14, 21, dan 28 hari. Setiap perlakuan dibuat lima kali sebagai ulangan. Silase dibuat menggunakan stoples plastik yang berfungsi sebagai silo. Setiap akhir pemeraman dilakukan uji kualitas meliputi warna, bau, tekstur, ada tidaknya jamur, kandungan bahan kering (BK), dan bahan organik (BO), serta $\mathrm{pH}$. Data $\mathrm{BK}, \mathrm{BO}$, dan $\mathrm{pH}$ dianalisis variansi menggunakan Randomized Completed Block Design (RCBD). Perbedaan yang nyata sebagai efek lama peram dilanjutkan uji Duncan's new Multiple Range Test (DMRT). Khusus dari hasil silase pemeraman 21 hari dilakukan analisis komposisi kimia meliputi serat kasar (SK), ekstrak eter (EE), dan protein kasar (PK). Data yang diperoleh dianalisis variansi menggunakan metode Rancangan Acak Lengkap pola searah. Perbedaan yang nyata sebagai efek perlakuan dilanjutkan uji DMRT. Uji kualitas fisik menunjukkan warna coklat kehijauan, bau asam, tekstur kasar, dan tidak ada pertumbuhan jamur. Penambahan onggok pada level yang berbeda meningkatkan $(\mathrm{P}<0,01)$ nilai komposisi kimia silase isi rumen sapi, yaitu $\mathrm{BK}$ dan $\mathrm{BO}$, sedangkan $\mathrm{SK}$, EE, dan PK mengalami penurunan $(\mathrm{P}<0,01)$. Penambahan onggok sebagai aditif pada pembuatan silase dari isi rumen sapi

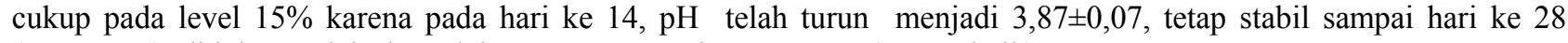
$(3,93 \pm 0,11)$, didukung oleh skor Fleig yang mencapai 98,58 $\pm 3,39$ (sangat baik).

(Kata kunci : Isi rumen sapi, Onggok, Lama peram, Silase)

\section{ABSTRACT}

This study was done to determine the effect of cassava pomace as additive on silage quality of rumen content. There were three levels of cassava pomace i.e. 0 (control), 15 and 30\% of rumen content (dry matter basis) then fermented for 14, 21 and 28 days. Samples were put in a jar as a silo in anaerobic condition. Each treatment was conducted on five replications. At the end of fermentation, physical quality tests, odor, texture, fungi, dry matter (DM), organic matter (OM) and $\mathrm{pH}$, of the silage were observed. Data of $\mathrm{pH}, \mathrm{DM}$ and $\mathrm{OM}$ were analyzed using variance analysis of Completely Randomized Block Design (RCBD) and continued by Duncan's new Multiple Range Test (DMRT). Samples of 21 days incubation, were used for chemical analysis e.g. crude protein (CP), crude fiber (CF) and ether extract (EE). The data obtained were analyzed by variance analysis of One-Way experimental design and continued by DMRT. The result showed that the silage had greeny-brown color, rough texture, acidic odor and no fungus had been found. Increasing level of cassava pomace addition increased $(P<0.01) D M$ and OM but decreased $(P<0.01)$ of $C P, C F$ and $E E$ of the silage. The best quality of silage was identified at addition of $15 \%$ cassava pomace, which is on day $14^{\text {th }}$, $p H$ was decreased to $3.87 \pm 0.07$ and relatively stabile until days $28^{\text {th }}$ (3.93 \pm 0.11 ). It also supported by Fleig score of $98.58 \pm 3.39$ (very good).

(Key words: Cattle rumen content, Cassava pomace, Duration of fermentation, Silage)

\section{Pendahuluan}

Keberhasilan usaha peternakan sangat ditentukan oleh kualitas, kuantitas, dan kontinuitas pakan yang diberikan. Pada musim kemarau pakan sulit diperoleh. Oleh karena itu, penting dilakukan penyiapan dan pengawetan pakan ternak yang akan

\footnotetext{
* Korespondensi (corresponding author):

Telp. +62 816689192

E-mail: ristianto_utomo@yahoo.com
}

digunakan, sehingga tersedia sepanjang tahun atau sepanjang pemeliharaan. Demikian juga penggalian bahan organik yang berpotensi untuk pakan alternatif perlu mendapat perhatian. Bahan organik tersebut antara lain isi rumen yang merupakan hasil samping rumah potong hewan (RPH).

Isi rumen sapi (IRS) dianggap sebagai limbah padat dari pemotongan sapi di RPH. Jumlah pemotongan sapi yang semakin meningkat menyebabkan limbah isi rumen sapi yang dihasilkan juga semakin meningkat. Di Daerah Istimewa 
Yogyakarta, jumlah pemotongan meningkat dari 19.635 ekor pada tahun 2009, menjadi 25.691 ekor pada tahun 2010, dan 35.741 ekor pada tahun 2011 (BPS DIY, 2012). Isi rumen sapi mengandung BK sekitar 12,50\%, PK 11,58\%, SK 24,01\%, EE $3,01 \%$, dan ekstrak tanpa nitrogen (ETN) 54,68\% (Utomo et al., 2007). Meskipun demikian komposisi kimia isi rumen ini tergantung juga pada pakan yang diberikan. Berdasarkan hasil analisis tersebut IRS masih layak digunakan untuk pakan sapi atau ruminansia yang lain.

Pada umumnya IRS yang dihasilkan di RPH hanya dibuang, sehingga menimbulkan cemaran baik dari bau yang sangat menyengat maupun dari sifatnya yang mudah busuk sehingga dapat menimbulkan berbagai macam penyakit. Salah satu cara untuk mengatasi hal tersebut adalah memanfaatkan IRS untuk pupuk. Selain itu dapat pula dengan dimanfaatkan sebagai pakan. Akan tetapi penggunaan IRS untuk pakan tidak dapat langsung diberikan karena bau yang menyengat sehingga ternak tidak mau memakannya. Selain itu karena berkadar air tinggi, IRS akan cepat busuk dan nutrien yang dikandungnya akan cepat mengalami kerusakan. Pembusukan dapat dicegah melalui metode pengawetan antara lain penjemuran atau pembuatan silase. Penjemuran merupakan salah satu pengawetan secara kering, sedangkan pembuatan silase merupakan pengawetan dalam keadaan segar. Selama penjemuran akan menyebabkan polusi udara, karena adanya bau yang khas dari isi rumen yang berasal dari asam lemak volatil. Untuk menghindari atau mengurangi polusi udara, salah satu alternatif yang dapat dilakukan adalah pembuatan silase. Pembuatan silase mempunyai beberapa persyaratan antara lain persentase BK sekitar 35\% dan kandungan karbohidrat mudah larut harus tinggi. Karbohidrat mudah larut berfungsi sebagai substrat terbentuknya asam laktat (Utomo, 2013).

Untuk memperoleh kandungan BK dan gula terlarut yang sesuai dengan kaidah pembuatan silase, maka dalam proses pembuatan silase isi rumen yang berkadar air tinggi $(87,50 \%)$ perlu ditambahkan bahan pakan yang mengandung BK dan karbohidrat mudah larut yang tinggi. Onggok kering merupakan ampas ketela pohon pada pembuatan pati. Kandungan BK onggok kering $84,41 \%$ (Utomo dan Soejono, 1990), 85,12\% (Isnandar, 2011) dan ETN 88,10\% (Utomo dan Soejono, 1990), 60,47\% (Isnandar, 2011), sehingga dapat digunakan sebagai aditif untuk menaikkan BK dan sumber karbohidrat mudah larut pada pembuatan silase.

Penelitian ini bertujuan untuk mengawetkan isi rumen sapi yang merupakan limbah rumah potong berkadar air tinggi dan mudah rusak, tetapi masih berpotensi untuk pakan sehingga dapat digunakan sebagai pengganti hijauan pakan.

\section{Materi dan Metode}

Penelitian ini dilaksanakan di Laboratorium Teknologi Makanan Ternak, Bagian Nutrisi dan Makanan Temak, Fakultas Peternakan, Universitas Gadjah Mada dari bulan Maret sampai Agustus 2011. Isi rumen sapi yang akan dibuat silase diambil dari RPH, onggok dari pedagang bahan pakan, dan bahan-bahan kimia untuk analisis proksimat dari Laboratorium Teknologi Makanan Ternak, Bagian Nutrisi dan Makanan Ternak, Fakultas Peternakan, Universitas Gadjah Mada.

Isi rumen yang digunakan dipilih dari sapi yang mengonsumsi hijauan pakan yang ditandai warna hijau. Isi rumen sapi diambil dari RPH Restu Bumi, Pleret, Bantul, dimasukkan ke dalam drum, diaduk sampai homogen dibagi ke dalam 3 ember untuk 3 perlakuan. Isi rumen yang digunakan mempunyai kadar air tinggi sekitar $80 \%$ atau mengandung BK 15-20\%, sehingga perlu penambahan bahan pakan lain yang berbahan kering tinggi, pada penelitian ini digunakan onggok. Penelitian pembuatan silase dari IRS dilakukan dengan tiga level penambahan onggok yaitu 0 sebagai kontrol, 15, dan 30\% dari berat BK. Setiap perlakuan dibuat lima kali ulangan, kemudian diperam dengan tiga lama peram yaitu 14,21 , dan 28 hari. Penetapan pada hari ke-14 dilakukan untuk mengetahui apakah fermentasi sudah berlangsung dengan baik. Hari ke-28 perlu dilakukan untuk mengetahui terjadi atau tidaknya fermentasi kedua yang mengarah terjadinya kerusakan karena terjadi pembusukan (putrification) yang disebabkan $\mathrm{pH}$ tidak turun maksimal atau terjadi kebocoran, sehingga bakteri pembentuk asam butirat dan pembusuk kembali aktif (Geasler dan Henderson, 1969 cit. Utomo, 2013; Mannetje, 2010).

Dalam penelitian ini digunakan dua rancangan yaitu Rancangan Blok Acak Lengkap (RBAL) dan Rancangan Acak Lengkap (RAL) pola searah. Pada RBAL, waktu peram sebagai blok untuk mengetahui perubahan selama waktu lama peram dan tiga level penggunaan onggok sebagai aditif terhadap kualitas silase isi rumen meliputi kualitas fisik, $\mathrm{pH}, \mathrm{BK}$, dan BO. Rancangan Acak Lengkap pola searah untuk mengetahui pengaruh tiga level penggunaan onggok terhadap komposisi kimia, $\mathrm{NH}_{3}, \mathrm{pH}$, dan skor Fleig silase yang berasal dari silase dengan waktu peram 21 hari (Astuti,1981; Gomez dan Gomez, 1984), karena pada proses silase sebenarnya berakhir pada hari ke 21 (Mannetje, 2010). 
Isi rumen sapi yang telah ditambah onggok dicampur secara merata kemudian dimasukkan ke dalam stoples plastik kapasitas $600 \mathrm{~g}$ yang digunakan sebagai silo sambil ditekan-tekan sampai padat sehingga udara keluar, keadaan hampir an aerob, kemudian ditutup rapat dan dilakukan pemeraman.

Silase IRS diperam selama 14, 21, dan 28 hari kemudian dipanen, dilakukan pengamatan fisik, penetapan $\mathrm{BK}, \mathrm{BO}$, dan $\mathrm{pH}$. Pengamatan secara fisik meliputi warna, tekstur, bau, serta ada tidaknya jamur dilakukan oleh panelis yang diambil dari mahasiswa yang telah mengambil mata kuliah Teknologi Pakan. Jumlah panelis sebanyak 3 orang, menggunakan blangko penilaian silase, pemberian skor menggunakan tanda (+/-) untuk masing-masing variabel sesuai kualitas fisik yang diamati. Skor yang diperoleh dari seluruh panelis untuk masingmasing kualitas fisik dirata-rata. Selain itu digunakan seperangkat peralatan analisis proksimat, pH meter (tipe HM-20J, TOA, DKK, JAPAN), timbangan analitik, dan spektrofotometer (GENESIS-20, THERMOSPECTRONIC, USA).

Pengukuran $\mathrm{pH}$ silase IRS dilakukan menggunakan $\mathrm{pH}$ meter digital setelah silase dipanen. Sebelum dilakukan penetapan $\mathrm{pH}$, sampel diberi aquades dengan perbandingan antara sampel dan aquades adalah 1 : 10 (Nahm, 1992). Penetapan $\mathrm{NH}_{3}$ dilakukan pada silase hasil pemeraman hari ke21, menggunakan spektrofotometer dengan cara mengambil sampel silase segar sebanyak $1 \mathrm{~g}$ ditambah aquades sebanyak $5 \mathrm{ml}$ (Chaney dan Marbach, 1962).

Sampel IRS hasil pemeraman 21 hari dikeringkan dalam oven pada temperatur $55^{\circ} \mathrm{C}$, kemudian digiling menggunakan willey mill dengan diameter lubang saringan berukuran $1 \mathrm{~mm}$. Selanjutnya digunakan untuk analisis proksimat (Harris, 1970; Nahm, 1992) meliputi penetapan BK, PK, SK, EE, dan ETN.

Kualitas silase ditentukan secara organoleptik (fisik) meliputi: tekstur, bau, dan rasa, serta secara laboratorium antara lain meliputi: $\mathrm{pH}$, kandungan asam laktat, asam asetat, asam butirat, dan $\mathrm{NH}_{3}$ (Utomo, 2013). Selain menggunakan cara tersebut menurut Santoso et al. (2009) dan Yildiz et al. (2010), kualitas silase juga dapat ditentukan menggunakan skor Fleig (SF), yang dihitung berdasar formula Kilic (1984), SF $=220+(2 \times \% \mathrm{BK}-15)$ $-(40 \times \mathrm{pH})$. Apabila SF silase diperoleh antara $85-$ 100 digolongkan berkualitas sangat baik, SF antara 60 - 80 digolongkan berkualitas baik, SF antara 55 - 60 digolongkan agak baik, SF antara $25-40$ digolongkan berkualitas sedang, jika $\mathrm{SF}<20$ digolongkan sangat jelek (Santoso et al., 2009).

\section{Hasil dan Pembahasan}

\section{Kualitas fisik silase isi rumen sapi}

Hasil penetapan kualitas fisik silase IRS yang pada pembuatannya diberi tiga level onggok sebagai aditif dan diperam dalam tiga waktu yang berbeda yaitu 14, 21, dan 28 hari disajikan pada Tabel 1.

Hasil uji kualitas fisik silase IRS secara umum dapat dikatakan baik ditinjau dari bau (asam), warna, dan tekstur. Menurut Utomo et al. (2008), selama proses silase seharusnya tidak terjadi respirasi yang berlebihan atau berkepanjangan. Respirasi berkepanjangan karena oksigen yang terperangkap banyak menyebabkan temperatur tinggi karena perombakan karbohidrat dan protein. Jika proses ini berjalan lama maka temperatur di dalam silo menjadi tinggi sehingga merusak warna hijauan (McDonald, 1991).

Warna silase yang baik adalah mendekati warna aslinya yaitu warna saat dibuat silase. Warna silase IRS saat dibuat berbeda dengan warna aslinya karena dipengaruhi oleh warna onggok yang ditambahkan sebagai aditif. Pemberian onggok yang terbaik ditunjukkan pada level $15 \%$, semakin tinggi level pemberian onggok menjadikan warna silase semakin kecoklatan. Warna coklat terjadi karena pengaruh penambahan onggok, sehingga semakin banyak onggok yang ditambahkan warna silase menjadi semakin jauh dari warna bahan aslinya.

Hasil pengamatan tekstur silase IRS dominan kasar pada berbagai level penambahan onggok. Level penggunaan onggok $15 \%$, pada lama peram 14 hari menunjukkan tekstur kasar dan masih tetap baik sampai hari ke-28. Silase tanpa penambahan onggok atau level $0 \%$ kondisi silase pada hari ke28 , tekstur lembut. Hal ini disebabkan karena tidak ada penambahan onggok sehingga sifat silase masih sama dengan isi rumen sapi awal.

Pengamatan bau silase IRS terbaik pada tingkat pemberian onggok $15 \%$ dan 30\% (Tabel 1) yaitu asam baik pada lama peram 14, 21, maupun 28 hari. Bau asam muncul karena terbentuknya asam terutama asam laktat hasil fermentasi yang dilakukan oleh bakteri asam laktat selama proses silase berlangsung. Pada level onggok $0 \%$ pada semua lama peram $(14,21$, dan 28 hari) tercium bau busuk. Hal ini disebabkan karena isi rumen yang dibuat masih sama seperti bahan asalnya, karena tanpa penambahan onggok. Keadaan ini menyebabkan tidak tersedia substrat berupa karbohidrat mudah larut yang cukup untuk bakteri asam laktat (BAL), dan kadar airnya masih tinggi, sehingga tidak terbentuk asam laktat. Bau silase secara umum asam. Hal ini disebabkan karena adanya produksi asam laktat selama proses fermentasi (Utomo, 2013). 
Tabel 1. Kualitas fisik silase isi rumen pada tiga level penambahan onggok pada hari ke-14, 21, dan 28 fermentasi (the quality of rumen content silage at three levels cassava pomace addition on days $14^{\text {th }}, 21^{\text {st }}$ and $28^{\text {th }}$ of fermentation)

\begin{tabular}{|c|c|c|c|c|}
\hline \multirow{2}{*}{$\begin{array}{l}\text { Variabel } \\
\text { (variable) }\end{array}$} & \multirow{2}{*}{$\begin{array}{c}\text { Onggok }(\% \mathrm{BK}) \\
\text { (cassava pomace } \\
(\% \text { DM) })\end{array}$} & \multicolumn{3}{|c|}{ Lama peram (hari) (fermented duration (days)) } \\
\hline & & 14 & 21 & 28 \\
\hline \multirow[t]{3}{*}{ Warna (color) } & 0 & $\begin{array}{l}\text { Hijau kecoklatan } \\
\text { (brownish green) }\end{array}$ & $\begin{array}{l}\text { Hijau kekuningan } \\
\text { (yellowish green) }\end{array}$ & $\begin{array}{l}\text { Hijau kekuningan } \\
\text { (yellowish green) }\end{array}$ \\
\hline & 15 & $\begin{array}{l}\text { Hijau kekuningan } \\
\text { (yellowish green) }\end{array}$ & $\begin{array}{l}\text { Hijau kecoklatan } \\
\text { (brownish green) }\end{array}$ & $\begin{array}{l}\text { Kuning kecoklatan } \\
\text { (tawny) }\end{array}$ \\
\hline & 30 & $\begin{array}{l}\text { Hijau kekuningan } \\
\text { (yellowish green) }\end{array}$ & $\begin{array}{l}\text { Kuning kecoklatan } \\
\text { (tawny) }\end{array}$ & Coklat (brown) \\
\hline \multirow[t]{3}{*}{ Tekstur (texture) } & 0 & Kasar (rough) & Kasar (rough) & Lembut (soft) \\
\hline & 15 & Kasar (rough) & Kasar (rough) & Kasar (rough) \\
\hline & 30 & Kasar (rough) & $\begin{array}{l}\text { Agak lembut } \\
\text { (rather soft) }\end{array}$ & Kasar (rough) \\
\hline \multirow[t]{3}{*}{ Bau (odor) } & 0 & Busuk (bad odor) & Busuk (bad odor) & Busuk (bad odor) \\
\hline & 15 & Asam (sour) & Asam (sour) & Asam (sour) \\
\hline & 30 & Asam (sour) & Asam (sour) & Asam (sour) \\
\hline \multirow[t]{3}{*}{ Jamur (fungi) } & 0 & $\begin{array}{l}\text { Tidak ada (un } \\
\text { identified) }\end{array}$ & $\begin{array}{l}\text { Tidak ada (un } \\
\text { identified) }\end{array}$ & $\begin{array}{l}\text { Tidak ada (un } \\
\text { identified) }\end{array}$ \\
\hline & 15 & $\begin{array}{l}\text { Tidak ada (un } \\
\text { identified) }\end{array}$ & Sedikit (trace) & Sedikit (trace) \\
\hline & 30 & $\begin{array}{l}\text { Tidak ada (un } \\
\text { identified) }\end{array}$ & Sedikit (trace) & Sedikit (trace) \\
\hline
\end{tabular}

Pada lama peram 21 hari dan 28 hari, di permukaan silase terdapat warna putih yang diduga jamur, tetapi hanya di permukaan. Hal ini disebabkan ada kebocoran pada silo akibat air tirisan yang terkandung dalam isi rumen keluar dari silo lewat tutup bagian pinggir, sehingga bagian atas (tutup) menjadi sedikit aerob saat air merembes keluar. Secara umum kualitas fisik silase yang baik sudah ditunjukkan oleh tingkat penambahan onggok $15 \%$ dan $30 \%$ pada lama peram 14 hari.

Salah satu cara yang dilakukan untuk mengetahui kualitas silase adalah dengan jalan mengukur atau menetapkan $\mathrm{pH}$ silase yang dihasilkan. Hasil penetapan tingkat keasaman $(\mathrm{pH})$ silase IRS dengan penambahan tiga level onggok $(0$, 15 , dan $30 \%$ ) pada lama fermentasi 14,21 , dan 28 hari tersaji pada Tabel 2.

Hasil analisis variansi menunjukkan bahwa terdapat penurunan $\mathrm{pH}$ secara tidak nyata pada lama peram 14, 21, dan 28 hari (Tabel 2). Hal ini menunjukkan bahwa proses silase berhasil dengan baik, karena $\mathrm{pH}$ pada hari ke-14 telah turun mencapai 4,37 dan tetap terjaga rendah $(4,36)$, sampai pada lama peram 28 hari. Tidak terjadinya perubahan (kenaikan) pH menunjukkan tidak terjadi fermentasi kedua seperti yang dinyatakan Geasler dan Henderson (1969) cit. Utomo (2013) bahwa fermentasi kedua dilakukan oleh bakteri pembentuk asam butirat dan pembusuk, mengarah pada kegagalan proses silase yang ditunjukkan oleh naiknya $\mathrm{pH}$ pada hari ke-28. Keadaan ini dapat disebabkan karena pada hari ke-21 $\mathrm{pH}$ belum dapat turun di bawah 4,5 atau terjadi kebocoran silo sehingga bakteri pembentuk asam butirat aktif.

Hasil penetapan $\mathrm{pH}$ pada penambahan onggok 15\% $(3,93)$ dan 30\% $(3,92)$, menunjukkan terjadi penurunan $\mathrm{pH}$ secara sangat nyata $(\mathrm{P}<0,01)$ dibanding tanpa penambahan onggok $(5,23)$, tetapi antara penambahan $30 \%$ dengan $15 \%$ tidak menunjukkan penurunan $\mathrm{pH}$ yang nyata. Keadaan ini menunjukkan bahwa penambahan onggok $15 \%$ pada pembuatan silase isi rumen sapi telah cukup menyediakan substrat bagi BAL untuk membentuk asam laktat sehingga terjadi penurunan $\mathrm{pH}$. Berbeda halnya dengan yang tanpa penambahan onggok $(0 \%) \mathrm{pH}$ yang terukur masih tinggi yaitu 5,23 $\pm 0,10$. Keadaan ini menunjukkan tidak terjadi proses silase karena tidak cukup tersedia substrat untuk BAL. Menurut Utomo (2013) pH dapat digunakan sebagai penentu kualitas silase pengganti variabel asam laktat pada silase yang berlangsung secara alami, karena nilai $\mathrm{pH}$ silase secara sangat nyata $(\mathrm{P}<0,01)$ berkorelasi negatif dengan kandungan asam laktat. Artinya semakin tinggi kandungan asam laktat dalam silase, pH-nya akan semakin rendah. Sehubungan dengan hal itu, dapat juga diambil hubungan sebab akibat, bahwa $\mathrm{pH}$ silase yang rendah karena kandungan asam laktatnya tinggi. 
Tabel 2. $\mathrm{pH}$ silase isi rumen sapi dengan tiga level penambahan onggok pada lama peram 14, 21, dan 28 hari fermentasi (the $\mathrm{pH}$ of rumen content silage at three levels cassava pomace addition on days $14^{\text {th }}, 21^{\text {st }}$ and $28^{\text {th }}$ of fermentation)

\begin{tabular}{|c|c|c|c|c|}
\hline \multirow{2}{*}{$\begin{array}{c}\text { Onggok (\% BK) (cassava pomace } \\
(\% \text { DM)) }\end{array}$} & \multicolumn{3}{|c|}{ Lama peram (hari) (fermented duration (days)) } & \multirow{2}{*}{$\begin{array}{c}\text { Rerata } \\
\text { (average) }\end{array}$} \\
\hline & 14 & 21 & 28 & \\
\hline 0 & $5,15 \pm 0,16$ & $5,25 \pm 0,01$ & $5,28 \pm 0,02$ & $5,23 \pm 0,10^{\mathrm{a}}$ \\
\hline 15 & $3,99 \pm 0,03$ & $3,87 \pm 0,07$ & $3,93 \pm 0,11$ & $3,93 \pm 0,09^{b}$ \\
\hline 30 & $3,96 \pm 0,04$ & $3,93 \pm 0,02$ & $3,87 \pm 0,01$ & $3,92 \pm 0,05^{b}$ \\
\hline Rerata (average) ${ }^{\mathrm{ns}}$ & $4,37 \pm 0,58$ & $4,35 \pm 0,66$ & $4,36 \pm 0,68$ & \\
\hline
\end{tabular}

${ }_{\mathrm{a}, \mathrm{b}}$ Superskrip yang berbeda pada kolom yang sama menunjukkan perbedaan yang sangat nyata $(\mathrm{P}<0,01)$

(different superscripts at the same column indicate significant differences $(P<0.01)$ ).

ns Tidak berbeda nyata (non significant).

Menurut McDonald et al. (1984), selama proses fermentasi berlangsung terdapat aktivitas BAL yang memfermentasi karbohidrat terlarut menjadi asam organik yang sebagian besar berupa asam laktat, sehingga $\mathrm{pH}$ menjadi lebih rendah dan menjadi lebih asam. Kualitas silase yang baik secara fisik, yaitu warna silase mendekati warna bahan asalnya, tekstur masih tampak jelas mirip asalnya, tidak menggumpal, tidak ditumbuhi jamur, tidak berlendir, tidak berbau manis, serta bau dan rasanya asam (Utomo, 2013).

\section{Bahan kering dan bahan organik}

Hasil analisis pengaruh penggunaan tiga level onggok sebagai aditif terhadap kadar BK dan BO silase isi rumen sapi pada hari ke-14, 21, dan 28 tercantum pada Tabel 3.

Hasil analisis variansi (Tabel 3) menunjukkan bahwa komposisi BK berbeda sangat nyata $(\mathrm{P}<0,01)$ pada level 0,15 , dan $30 \%$ yaitu $17,26 \pm 1,26 ; 24,34 \pm 0,80$; dan $30,00 \pm 1,13$. Semakin tinggi level penambahan onggok menunjukkan terjadinya peningkatan BK. Menurut Parakkasi (1995) proses fermentasi yang berlebihan dapat menyebabkan kehilangan zat makanan yang dapat mencapai 25\% BK, umumnya antara 5-19\% BK, sedangkan menurut Utomo (2013) sebaik-baiknya proses silase akan kehilangan BK minimal 10\%. Sejalan dengan pernyataan tersebut, berarti tidak terjadi fermentasi kedua (second fermentation) pada pembuatan silase isi rumen sapi. Hal Ini yang menyebabkan kehilangan BK dalam jumlah yang banyak. Isnandar (2011) menyatakan bahwa kandungan BK dan kandungan gula terlarut isi rumen yang rendah, dapat ditingkatkan dengan penambahan bahan aditif yang dapat meningkatkan kandungan BK dan kandungan gula terlarut ideal. Penambahan limbah industri pertanian dan perkebunan berupa onggok dan molases pada isi rumen meningkatkan BK dan ketersediaan gula terlarut karena kandungan BK onggok dan kandungan gula terlarut molases yang tinggi.
Pembuatan silase dari bahan limbah pertanian dan peternakan dengan kandungan BK rendah sehingga tidak memenuhi syarat untuk dibuat silase, dapat ditambahkan bahan aditif yang dapat menurunkan kadar air atau meningkatkan kandungan BK silase sampai pada kandungan yang diinginkan sekitar 35\% (Chedly et al., 2000 cit. Isnandar, 2011; Utomo, 2013). Menurut Utomo et al. (2008) komposisi dan kualitas silase dapat diperbaiki dengan penambahan aditif silase sumber karbohidrat mudah larut antara lain onggok kering, untuk menaikkan BK, membantu mempercepat proses fermentasi, dan mempertahankan atau meningkatkan nutrien bahan pakan yang diawetkan.

Hasil analisis variansi pada lama peram 14, 21, dan 28 hari menunjukkan bahwa lama peram (hari) berpengaruh tidak nyata terhadap perubahan kandungan BK dan BO silase isi rumen sapi. Hal ini menunjukkan tidak terjadi fermentasi yang menjurus pada kerusakan yang menurunkan kualitas. Akan tetapi hasil analisis variansi pada tingkat pemberian onggok menunjukkan pengaruh yang sangat nyata $(\mathrm{P}<0,01)$ terhadap peningkatan kandungan $\mathrm{BO}$. Pemberian onggok meningkatkan BO secara sangat signifikan $(\mathrm{P}<0,01)$ dari $85,55 \pm 2,13$ (level 0\%) ke 90,17 $\pm 0,36$ (level 15\%) dan ke 92,52 $\pm 0,38$ (pada level 30\%), sedangkan dari penambahan $15 \%$ ke $30 \%$ tidak terjadi kenaikan BO secara nyata. Peningkatan BO disebabkan oleh adanya penambahan onggok. Semakin tinggi level penambahan onggok pada isi rumen sapi yang dibuat silase, BO silase akan semakin meningkat. Hal ini disebabkan karena tingginya kandungan BO onggok yaitu sebesar 98,50\% (Utomo dan Soejono, 1990).

\section{Kualitas silase IRS hari ke dua puluh satu}

Hasil penetapan kualitas silase IRS berdasarkan hasil pengamatan fisik meliputi warna, tekstur, dan bau, serta penetapan $\mathrm{pH}$ kandungan $\mathrm{NH}_{3}$, dan SF dari pemeraman selama 21 hari 
Tabel 3. Rerata BK dan BO silase isi rumen sapi dengan tiga level onggok sebagai aditif pada hari ke-14, 21, dan 28 hari fermentasi (the average of dry matter (DM) and organic matter (OM) of rumen content silage at three levels cassava pomace addition on days $14^{\text {th }}, 21^{\text {st }}$ and $28^{\text {th }}$ fermentation)

\begin{tabular}{|c|c|c|c|c|c|}
\hline \multirow{2}{*}{$\begin{array}{l}\text { Variabel } \\
\text { (variable) }\end{array}$} & \multirow{2}{*}{$\begin{array}{c}\text { Onggok (\% BK) (cassava } \\
\text { pomace }(\% \text { DM) }\end{array}$} & \multicolumn{3}{|c|}{ Lama peram (hari) (fermented duration (days)) } & \multirow{2}{*}{$\begin{array}{c}\text { Rerata } \\
\text { (average) }\end{array}$} \\
\hline & & 14 & 21 & 28 & \\
\hline $\mathrm{BK} / \mathrm{DM}$ & 0 & $15,69 \pm 0,86$ & $18,04 \pm 0,12$ & $18,07 \pm 0,41$ & $17,26 \pm 1,26$ \\
\hline \multirow[t]{3}{*}{$(\%)$} & 15 & $24,18 \pm 0,76$ & $24,20 \pm 0,29$ & $24,65 \pm 1,20$ & $24,34 \pm 0,80^{1}$ \\
\hline & 30 & $30,51 \pm 1,37$ & $29,35 \pm 0,61$ & $30,14 \pm 1,15$ & $30,00 \pm 1,13^{\mathrm{a}}$ \\
\hline & Rerata (average) ${ }^{n \mathrm{~s}}$ & $23,46 \pm 6,36$ & $23,87 \pm 4,80$ & $24,28 \pm 5,19$ & \\
\hline $\mathrm{BO} / \mathrm{OM}$ & 0 & $86,55 \pm 0,19$ & $83,47 \pm 2,77$ & $86,65 \pm 0,09$ & $85,55 \pm 2,13^{\mathrm{b}}$ \\
\hline \multirow[t]{3}{*}{$(\%)$} & 15 & $90,15 \pm 0,23$ & $90,12 \pm 0,53$ & $90,26 \pm 0,31$ & $90,17 \pm 0,36^{\mathrm{a}}$ \\
\hline & 30 & $92,31 \pm 0,52$ & $92,65 \pm 0,26$ & $92,60 \pm 0,30$ & $92,52 \pm 0,38^{\mathrm{a}}$ \\
\hline & Rerata (average) ${ }^{\mathrm{ns}}$ & $89,67 \pm 2,48$ & $88,74 \pm 4,28$ & $89,83 \pm 2,55$ & \\
\hline
\end{tabular}

BK/DM: bahan kering (dry matter).

BO/OM: bahan organik (organic matter).

a,b,c Superskrip yang berbeda pada kolom yang sama menunjukkan perbedaan yang sangat nyata $(\mathrm{P}<0,01)$ pada kandungan $\mathrm{BK}$ atau $\mathrm{BO}$ (different superscripts at the same column indicate significant differences $(P<0.01)$ at data $D M / O M)$.

ns Tidak berbeda nyata (non significant).

dengan tiga level penambahan onggok $(0,15$, dan $30 \%$ ) disajikan pada Tabel 4.

Derajad keasaman (pH). Dari hasil penetapan $\mathrm{pH}$ silase pada lama peram 21 hari (Tabel 4) diperoleh bahwa pemberian onggok sebanyak $15 \%$ berpengaruh secara sangat nyata $(\mathrm{P}<0,01)$ terhadap rata-rata penurunan $\mathrm{pH}$, sedangkan penambahan onggok sebanyak $30 \%$ berbeda tidak nyata dengan penambahan sebanyak $15 \%$. Hal ini menunjukkan bahwa penambahan atau penggunaan onggok sebagai aditif pada pembuatan silase isi rumen cukup dilakukan pada level $15 \%$.

Kadar amonia. Penurunan $\mathrm{pH}$ berpengaruh pada terbentuknya $\mathrm{NH}_{3}$ karena tidak terjadi hidrolisis protein. Hal ini berarti semakin rendah kandungan $\mathrm{NH}_{3}$ suatu silase dapat dikatakan semakin baik kualitasnya. Keadaan ini dapat dilihat pada silase tanpa penambahan onggok $(0 \%)$ yang $\mathrm{pH}$-nya tinggi kandungan $\mathrm{NH}_{3}$ nya juga tinggi. Kandungan $\mathrm{NH}_{3}$ silase yang baik antara 1,02-2,87\% BK (Geasler dan Henderson, 1969 cit. Utomo, 2013), sedangkan dalam penelitian ini adalah $0,19 \pm 0,01$ pada level onggok $15 \%$ (Tabel 4).

Skor Fleig. Penambahan onggok menaikkan skor Fleig secara sangat nyata dari $30,85 \pm 0,65$ (tanpa penambahan onggok) menjadi $98,58 \pm 3,39$ dan $106,84 \pm 1,37$ pada penambahan onggok 15 dan $30 \%$. Dengan demikian dapat dikatakan bahwa penggunaan onggok sebanyak $15 \%$ sudah menghasilkan silase yang berkualitas sangat baik, karena skor Fleig yang diperoleh mendekati 100 (Santoso et al., 2009), bahkan pada penggunaan onggok 30\% diperoleh skor Fleig lebih dari 100.

Prinsip pembuatan silase adalah fermentasi oleh bakteri asam laktat secara anaerob. Proses fermentasi bertujuan untuk menstimulir terbentuknya asam laktat sehingga akan menaikkan derajad keasaman ( $\mathrm{pH}$ rendah), pada $\mathrm{pH}$ rendah akan menghambat pembusukan mencegah kerusakan pada hasil silase isi rumen sapi. Menurut Utomo et al. (2008) akumulasi asam laktat dapat menghambat aktivitas biologis biomassa hijauan yang dibuat silase sehingga bahan pakan menjadi awet dan tahan lama dalam penyimpanan.

\section{Komposisi kimia silase isi rumen sapi}

Hasil analisis komposisi kimia meliputi BK, BO, PK, SK, dan EE silase IRS pada lama peram 21 hari dengan tiga level penggunaan onggok sebagai aditif tersaji pada Tabel 5 .

Hasil analisis variansi (Tabel 5) menunjukkan bahwa tingkat penambahan onggok menyebabkan peningkatan secara sangat nyata $(\mathrm{P}<0,01)$ BK silase IRS dibandingkan dengan kontrol $(0 \%)$. Kandungan BK silase meningkat karena dipengaruhi oleh BK onggok (89,37\%), sedangkan BK IRS hanya $12,50 \%$ (Utomo et al., 2007). Komposisi dan kualitas silase dapat diperbaiki dengan penambahan aditif silase untuk membantu mempercepat proses fermentasi dan membantu mempertahankan atau meningkatkan nutrien bahan pakan yang diawetkan (Utomo et al., 2008).

Hasil analisis variansi (Tabel 5) menunjukkan bahwa level penambahan onggok $30 \%$ secara sangat nyata $(\mathrm{P}<0,01)$ menurunkan $\mathrm{PK}$ silase isi rumen sapi dibandingkan dengan kontrol $(0 \%)$ dan $15 \%$, sedangkan penambahan onggok $15 \%$ belum menurunkan kandungan protein kasar secara nyata. Kandungan PK silase isi rumen sapi menurun secara sangat nyata $(\mathrm{P}<0,01)$ pada penggunaan 
Tabel 4. Parameter $\mathrm{pH}, \mathrm{NH}_{3}$, dan skor Fleig silase IRS dengan tiga level penambahan onggok pada 21 hari fermentasi (the $\mathrm{pH}, \mathrm{NH}_{3}$ and Fleig score of rumen content silage at three levels cassava pomace addition on days $21^{\text {st }}$ fermentation)

\begin{tabular}{lccc}
\hline \hline \multirow{2}{*}{ Variabel (variable) } & \multicolumn{3}{c}{ Level onggok (\%) (cassava pomace level $(\%))$} \\
\cline { 2 - 4 } $\mathrm{pH}$ & 0 & 15 & 30 \\
$\mathrm{NH}$ & $5,25 \pm 0,0 \mathrm{I}^{\mathrm{a}}$ & $3,87 \pm 0,07^{\mathrm{b}}$ & $3,93 \pm 0,02^{\mathrm{b}}$ \\
Skor Fleig $(\mathrm{SF})($ Fleig score $(\mathrm{FS}))$ & $0,65 \pm 0,12^{\mathrm{a}}$ & $0,19 \pm 0,01^{\mathrm{b}}$ & $0,21 \pm 0,01^{\mathrm{b}}$ \\
a,b,c Superskrip yang berbeda pada baris yang sama menunjukkan perbedaan yang sangat nyata $(\mathrm{P}<0,01)$ \\
\multicolumn{3}{c}{ (different superscripts at the same row indicate significant differences $(\mathrm{P}<0.01))}$.
\end{tabular}

Tabel 5. Rerata komposisi kimia silase isi rumen sapi (\%BK) pada tiga level penambahan onggok pada hari ke-21 fermentasi (the average of chemical composition of rumen content silage (\% DM) at three levels cassava pomace addition on days $21^{\text {st }}$ fermentation)

\begin{tabular}{lrrr}
\hline \hline \multirow{2}{*}{ Komposisi kimia (\%) (chemical composition (\%)) } & \multicolumn{3}{c}{ Level onggok (\%) (cassava pomace level (\%)) } \\
\cline { 2 - 4 } & 0 & 15 & \multicolumn{1}{c}{30} \\
\hline Bahan kering (dry matter) & $18,01 \pm 0,18^{\mathrm{a}}$ & $24,27 \pm 0,61^{\mathrm{b}}$ & $29,44 \pm 0,62^{\mathrm{c}}$ \\
Bahan organik (organic matter) & $83,47 \pm 2,77^{\mathrm{a}}$ & $90,12 \pm 0,53^{\mathrm{b}}$ & $92,65 \pm 0,26^{\mathrm{b}}$ \\
Protein kasar (crude protein) & $9,76 \pm 0,37^{\mathrm{a}}$ & $9,63 \pm 1,08^{\mathrm{a}}$ & $6,92 \pm 0,26^{\mathrm{b}}$ \\
Ekstrak ether (ether extract) & $5,72 \pm 0,66^{\mathrm{a}}$ & $4,25 \pm 0,17^{\mathrm{b}}$ & $2,24 \pm 0,09^{\mathrm{c}}$ \\
Serat kasar (crude fiber) & $34,79 \pm 0,27^{\mathrm{a}}$ & $27,59 \pm 0,83^{\mathrm{b}}$ & $17,82 \pm 0,80^{\mathrm{c}}$ \\
\hline a,b,c Superskrip yang berbeda pada baris yang sama menunjukkan perbedaan yang sangat nyata $(\mathrm{P}<0,01)$ & \\
\multicolumn{2}{c}{ (different superscripts at the same row indicate significant differences $(P<0.01))}$.
\end{tabular}

onggok sebagai aditif sebanyak $30 \%$. Hal ini disebabkan kandungan PK onggok sangat rendah. Onggok merupakan bahan pakan sumber energi yang mempunyai kadar protein kasar sangat rendah, hanya 1,13\% (Utomo dan Soejono, 1990), 1,61\% (Utomo, 2012), dan 0,97\% (Utomo et al., 2007).

Hasil analisis variansi (Tabel 5) menunjukkan bahwa level penambahan onggok sangat nyata $(\mathrm{P}<0,01)$ menurunkan EE silase isi rumen dibandingkan dengan kontrol (0\%). Penurunan tertinggi pada penggunaan onggok pada level $30 \%$, sehingga kadar EE tinggal 2,24 $\pm 0,09$. Hal ini disebabkan karena kadar lemak kasar atau EE onggok sangat rendah, dapat dikatakan mendekati $0 \%$ (Utomo dan Soejono, 1990) dan 0,33\% (Utomo et al., 2007).

Hasil analisis variansi (Tabel 5) menunjukkan bahwa penambahan level onggok sebagai aditif menurunkan secara sangat nyata $(\mathrm{P}<0,01)$ kandungan SK silase isi rumen sapi dibandingkan dengan kontrol (0\%). Penurunan kadar SK tertinggi pada level penggunaan onggok sebanyak 30\%, sehingga kadar SK tinggal $17,82 \%$. Hal ini disebabkan karena kandungan SK onggok rendah hanya 9,18\% (Utomo dan Soejono, 1990), dan 15,20\% (Utomo, 2012).

Penurunan kadar SK berpengaruh baik terhadap kualitas silase karena SK yang terlalu tinggi dapat mengganggu pencernaan zat-zat lainnya, sehingga kecernaan bahan pakan menjadi rendah, hal ini disebabkan karena untuk mencema serat kasar diperlukan banyak energi (Lubis, 1992).

\section{Kesimpulan dan Saran}

\section{Kesimpulan}

Penambahan onggok sebagai aditif pembuatan silase dari isi rumen sapi cukup pada level $15 \%$ karena pada hari ke-14, $\mathrm{pH}$ telah turun menjadi $3,87 \pm 0,07$ dan tetap stabil sampai hari ke$28(3,93 \pm 0,11)$, didukung oleh skor Fleig $98,58 \pm 3,39$ (sangat baik) meskipun bahan kering (\%) yang diperoleh $24,27 \pm 0,61$, masih di bawah bahan kering minimal syarat silase $(25 \%)$.

\section{Saran}

Saat pelaksanaan, sebelum pembuatan silase, kadar air isi rumen diturunkan dengan jalan diperas. Pemerasan akan mengurangi kadar air, sehingga setelah ditambah $15 \%$ onggok atau kurang sudah memenuhi syarat bahan kering yang ideal untuk pembuatan silase. Namun demikian pemerasan diduga akan mengurangi kualitas isi rumen karena nutrien yang larut dalam cairan rumen akan ikut terperas.

\section{Ucapan Terima Kasih}

Pada kesempatan ini penulis mengucapkan terima kasih yang sebesar-besarnya kepada saudara 
Untung Sahpono selaku laboran, saudara Marwoto yang membantu menyiapkan peralatan, dan khemikalia untuk pelaksanaan penelitian ini.

\section{Daftar Pustaka}

Astuti, M. 1981. Rancangan Percobaan dan Analisis Statistik Bagian II (Randomized Complete Block Designs. Repeated Measurement and Split Plot Designs). Bagian Pemuliaan Ternak. Fakultas Peternakan. Universitas Gadjah Mada. Yogyakarta.

BPS DIY. 2012. Daerah Istimewa Yogyakarta Dalam Angka. Badan Pusat Statistik Provinsi Daerah Istimewa Yogyakarta.

Chaney, A. L. and E. P. Marbach. 1962. Modified reagent for determination of urea and ammonia. Clinical Chemestry J. 8: 130-132.

Gomez, K. A. and A. A. Gomez. 1984. Statistic Procedure for Agricultural Research. Second Edition. An International Rice Reseach Intitue Book. Copyright John Wiley and Sons Inc. New York. Toronto.

Harris, L. E. 1970. Chemical and Biological Methods for Feeds Analysis. Center for Tropical Agric. Feed Composition Project. Livestock Pavilion University of Florida, Gainesville Florida.

Isnandar. 2011. Silase Isi rumen sebagai pengganti hijauan jagung terhadap produksi susu sapi perah Peranakan Friesian Holstein. Disertasi. Program Pascasarjana. Universitas Gadjah Mada Yogyakarta.

Lubis, D. A. 1992. Ilmu Makanan Ternak. Cetakan Ulang. PT. Pembangunan. Jakarta.

Mannetje, L. 2010. Silage for Animal Feed. Encyclopedia of Life Support System (EOLSS), Biotecnology VIII: 123-135. Available at http://www.eolss.net/ SampleChapters/C17/E6-58-07-05.pdf. Accession date: March 19, 2013.

McDonald, P. 1991. The Biochemestry of Silage. John Willley and Sons. New York.
McDonald, P., R. A. Edwards and J. F. D. Greenhalgh. 1984. Animal Nutrition. $4^{\text {th }}$ ed. English Language Book Society. Longman, London.

Nahm, K. H. 1992. Practical Guide to Feed, Forage and Water Analysis. Copyright by Yoo Han Publishing Inc. Seoul.

Santoso, B., B. Tj. Hariadi, H. Manik, dan H. Abubakar. 2009. Kualitas rumput unggul tropika hasil ensilase dengan bakteri asam laktat dari ekstrak rumput terfermentasi. Jurnal Media Peternakan 32: 137-144.

Utomo, R. 2012. Bahan Pakan Berserat untuk Sapi. Cetakan Pertama. PT. Citra Aji Parama. Yogyakarta.

Utomo, R. 2013. Konservasi Hijauan Pakan dan Peningkatan Kualitas Bahan Pakan Berserat Tinggi. In Press.

Utomo, R. dan M. Soejono. 1990. Pengaruh pemberian konsentrat terhadap kenaikan berat badan sapi Peranakan Ongole. Laporan Penelitian. Fakultas Peternakan Universitas Gadjah Mada. Dibiayai P4M, Ditjen DikTi DepDikBud, RI.

Utomo, R., L. M. Yusiati, U. Umiyasih, Aryogi, dan Isnandar. 2007. Pemanfaatan isi rumah potong hewan sebagai pakan alternatif pengganti hijauan. Laporan Penelitian. Universitas Gadjah Mada, Bekerjasama dengan Sekretariat Badan Penelitian dan Pengembangan Pertanian, DEPTAN.

Utomo, R., S. P. S. Budhi, A. Agus, dan C. T. Noviandi. 2008. Teknologi dan Fabrikasi Pakan. Hand Out. Laboratorium Teknologi Makanan Ternak. Fakultas Peternakan Universitas Gadjah Mada, Yogyakarta.

Yildiz, C., I. Ozturk and Y. Erkmen. 2010. Effect of chopping length and compaction values on the feed qualities of sunflower silage. Scientific Research and Essays 5: 2051-2054. Available at http/www.academic journals.org/SRE. Accession date: March 19, 2013. 